Bir Diş Hekimliği

fakültesine başvuran

hastaların diş

hekimliği uzmanlık

alanları konusundaki

bilgi düzeyleri

\section{Knowledge on dental specialties among dental patients who referred to a dental faculty}

Yrd. Doç. Dr. Melek Taşsöker

Necmettin Erbakan Üniversitesi Diş Hekimliği

Fakültesi, Ağız, Diş ve Çene Radyolojisi A.D., Konya

Yrd. Doç. Dr. Hatice Kök

Necmettin Erbakan Üniversitesi Diş Hekimliği

Fakültesi, Ortodonti A.D., Konya

Doç. Dr. Sevgi Özcan Şener

Necmettin Erbakan Üniversitesi Diş Hekimliği

Fakültesi, Ağız, Diş ve Çene Radyolojisi A.D., Konya

Geliş tarihi: 08 Mart 2017

Kabul tarihi: 04 Nisan 2017

doi: 10.5505/yeditepe.2017.47966

\section{Yazışma adresi:}

Yrd. Doç. Dr. Melek Taşsöker

Necmettin Erbakan Üniversitesi Diş Hekimliği

Fakültesi,

Ağız, Diş ve Çene Radyolojisi AD, 42050, Karatay,

KONYA

Tel: 3322200025-1126

E-posta: dishekmelek@gmail.com
ÖZET

Amaç: Bu çalışmanın amacı Necmettin Erbakan Üniversitesi Diş Hekimliği Fakültesi'ne başvuran hastaların diş hekimliği uzmanlık alanları konusundaki bilgi düzeylerini değerlendirmektir.

Gereç ve Yöntem: Hastaların diş hekimliği uzmanlık alanları konusundaki bilgi düzeylerini değerlendirmek amacıyla hazırlanan anket, lise ve üzeri eğitim durumuna sahip, tamamı internet kullanıcısı olan 1000 hasta ve fakültemizde farklı birimlerde görevli diş hekimi olmayan 38 çalışana uygulanmıştır. Karşılaştırmalar için ki-kare testi uygulanmış olup, önemlilik derecesi $\mathrm{p}<0,05$ olarak ele alınmıştır.

Bulgular: Hastaların en fazla doğru yanıtladıkları uzmanlık alanı ağız, diş ve çene radyolojisi (\%62,9), en fazla yanlış yanıt verdikleri uzmanlık alanı periodontoloji (\%41) olurken, yakın çevrede diş hekimi olmasının ve medeni durumunun verilen cevaplar üzerinde etkisi olmadığı gözlenmiş $(p>0,05)$; cinsiyet, eğitim durumu, gelir düzeyi, diş hekimi ziyareti sıklığı parametreleri ile verilen cevaplar arasında anlamlı farklııklar saptanmıştır $(p<0,05)$.

Sonuç: Diş hekimliği fakültesine başvuran bireylerde başta Ağız, Diş ve Çene Radyolojisi olmak üzere sırasıyla Çocuk Diş Hekimliği, Ağız, Diş ve Çene Cerrahisi ve Ortodonti diğer uzmanlık alanlarından daha fazla doğru bilinme oranına sahiptir. Bu bilgi toplum genelini yansıtmamakla birlikte gelecekte daha geniş kitlelerle yapılacak çalışmalara intiyaç vardır.

Anahtar Kelimeler: Diş hekimliğinde uzmanlık, bilgi düzeyi, hasta

\section{SUMMARY}

Aim: The aim of this study was to evaluate the knowledge on dental specialties among patients who referred to the Faculty of Dentistry, Necmettin Erbakan University.

Materials and Method: A questionnaire regarding the knowledge of patients about dental specialties was applied on 1000 patients, all of which were internet users, with high school and/or upper education level, as well as 38 staff from different units. Chi-square test was used for comparisons with a significance level at $p<0.05$.

Results: The most well-known dental specialty was Oral and Maxillofacial Radiology (62.9\%), while the least known dental specialty was Periodontology ( $41 \%)$. In terms of having a dentist friend/family member and marital status, there were no significant differences between the answers $(p>0.05)$ whereas significant differences were found between the answers in terms of gender, frequency of dental visit and level of education and income $(p<0.05)$.

Conclusion: Oral and Maxillofacial Radiology, followed by Pedodontics, Oral and Maxillofacial Surgery and Orthodontics, were found to be the most known specialties among dental patients who referred to the Faculty of Dentistry. Data gathered from this study does not reflect the general society and future studies on larger scales are needed.

Key words: Dental specialty, knowledge, patient 


\section{GíRiş}

Modern diş hekimliği, Pierre Fauchard'ın katkılarıyla, 18. yüzyılda tıptan ayrılarak bağımsız bir meslek dalı haline gelmeye başlamıştır. ${ }^{1,2}$ Türk diş hekimliği tarihi açısından önemli bir dönüm noktası olan İstanbul Diş Hekimliği Okulu açılıncaya kadar gerek Selçuklular döneminde gerekse Osmanlılar döneminde dişçilik sanatı, cerrahlar ve görgüye dayanarak kendi kendini yetiştirmiş kimseler tarafından uygulanmıştır. O dönemlerde genel olarak diş apselerini boşaltmaya cerrahlar yetkili olmakla birlikte, isteyen herkes diş çekebilmekteydi. ${ }^{3}$

Modern diş hekimliğinin gelişimi on sekizinci yüzyılda, bu yüzyılın en gelişmiş ve kültürel anlamda en zengin ülkesi Fransa ve İngiltere başta olmak üzere Avrupa'da gerçekleşmiştir. Modern diş hekimliğinin babası olarak kabul edilen Pierre Fauchard'ın (1678-1761) 1728 yılında yayımlanan kitabı 'Le Chrurgien Dentist- The Surgeon Dentist-Cerrah Diş Hekimi" restoratif diş hekimliği, protez, ağız cerrahisi, periodontoloji, ve ortodonti bölümlerinden oluşmaktaydı. ${ }^{4}$

Diş hekimliğinde branşlaşma 19. yüzyılda cerrahi ve ortodonti alanlarında başlamıştır. Buna ilişkin olarak; 1840 yılında Horace Hayden ve Chapin Harris Amerika'da Baltimore Diş Hekimliği Cerrahisi Okulunu açmışlar ve ilk kez diş hekimliği cerrahı unvanı bu okulda verilmiştir. ${ }^{4}$

Amerikalı diş hekimi Edward Hartley Angle (1855-1930), ortodonti bilim dalının kurucusu ve modern ortodontinin babası olarak tanınmaktadır. Onun liderliğinde ortodonti diş hekimliğinden ayrı bir dal haline gelmiş ve 1899 yılında ilk ortodonti okulu 'The Angle School of Orthodontia' St. Louis, Missouri'de açılmıştır. ${ }^{5,6}$

20. yüzyılda tıp bilimlerindeki gelişmelere paralel bir şekilde diş hekimliği uygulamalarında da kendine özgü gelişmeler meydana gelmiştir. Bilimsel gelişmelerle birlikte ulaşılan bilgi düzeyi ve buna bağlı olarak uygulamaların farklılaşması ve çeşitlenmesi, tıp alanında olduğu gibi diş hekimliği alanında da branşlaşmayı ve uzmanlaşmayı zorunlu kılmıştır. Genel tıp ve diş hekimliğinin ortak bir tarihsel gelişim sürecinden geçtiği ve önce genel tıp, sonra cerrahi ve diş hekimliğinin kendilerine özgü alanlara ayrıldığı bilinmektedir. Özellikle 20. yüzyılın başından itibaren genel tıbbın diğer alanlarında olduğu gibi diş hekimliği alanında da uzmanlaşma artarak devam etmektedir. ${ }^{4}$ 26.04.2011 tarih ve 27916 sayılı Resmi Gazete'de yayınlanan 6225 sayılı "Torba Yasa"da, diş hekimliğinin; Ağız, Diş ve Çene Cerrahisi, Ağız, Diş ve Çene Radyolojisi, Çocuk Diş Hekimliği, Endodonti, Ortodonti, Periodontoloji, Protetik Diş Tedavisi ve Restoratif Diş Tedavisi şeklindeki 8 ayrı çalışma alanı uzmanlık dalı olarak belirlenmiştir.? Çalışmamızın amacı; diş hekimliği fakültesine ilk muayene amacıyla başvuran hastalarda, diş hekimliğinin Türkiye'de kabul edilmiş 8 uzmanlık alanı konusundaki bilgi düzeyleri ve bunun farklı parametrelerle ilişkisini değer- lendirmektir. Bilgimiz dahilinde literatürde bu konuda yapılan bir çalışma bulunmamaktadır.

\section{GEREÇ VE YÖNTEM}

Çalışma ilk muayene amacıyla Ağız, Diş ve Çene Radyolojisi kliniğimize başvuran hastalarda, Necmettin Erbakan Üniversitesi Diş Hekimliği Fakültesi "ilaç ve Tıbbi Cihaz Dışı Araştırmalar Etik Kurulu" izni (sayı:2016/003) ile yürütülmüştür. Çalışmamıza 16-55 yaş aralığında, lise ve üstü eğitim seviyesine sahip, tamamı internet kullanıcısı olan, 552 kadın (yaş ort: $29 \pm 9,7$ ), 448 erkek (yaş ort: $33,8 \pm 8,3$ ) olmak üzere toplam 1000 birey (yaş ort: $31 \pm 9,3$ ) dahil edilmiştir. Bunun yanı sıra fakültemizde farklı birimlerde görevli, diş hekimi olmayan yaş aralığı 20-45, yaş ortalaması 31,8 6 ,5 olan 38 çalışan (23 kadın ve 15 erkek) da anketimize katılmıştır.

Anketin ilk bölümünde bireylerin yaş, cinsiyet, medeni durum, eğitim durumu, gelir seviyesi ve diş hekimine gitme sıklığı kaydedilmiştir. Ankette ikinci bölümde yer alan sorular hazırlanırken ilgili diş hekimliği uzmanlık alanının komplike olmayacak şekilde içeriği verilerek bu uygulamaların gerçekleştirildiği bölümü, hastanın şıklardaki 8 uzmanlık alanından biri ile eşleştirmesi, bilmediği soruya bilmiyorum seçeneğini işaretlemesi istenmiştir. 8 diş hekimliği uzmanlık alanı için hazırlanan 8 soru aşağıdaki şekilde uygulanmıştır:

1-Diş hekimliğinde; diş çekimlerinin, kist-tümör operasyonlarının gerçekleştirildiği uzmanlık alanı hangisidir? 2-Diş hekimliğinde; diş eti ameliyatlarının, diş taşı temizliğinin gerçekleştirildiği uzmanlık alanı hangisidir?

3-Diş hekimliğinde; çocuk hastaların tedavileri ile ilgilenen uzmanlık alanı hangisidir?

4-Diş hekimliğinde; kanal tedavilerinin gerçekleştirildiği uzmanlık alanı hangisidir?

5-Diş hekimliğinde; tanıya yönelik görüntüleme işlemlerinin ve tedavi planlamasının yapıldığı uzmanlık alanı hangisidir?

6-Diş hekimliğinde; amalgam, kompozit gibi dolgu materyalleri yardımıyla çürüklerin tedavisinin yapıldığı uzmanlık alanı hangisidir?

7-Diş hekimliğinde; diş çapraşıklıklarının tedavisi ile ilgilenen uzmanlık alanı hangisidir?

8-Diş hekimliğinde; sabit ya da hareketli alternatiflerle diş eksikliklerinin tedavisini gerçekleştiren uzmanlık alanı hangisidir?

Anket sorularının yanıtları nitel olduğu için verilen cevaplar ile diğer parametreler arasındaki ilişki ki-kare testi ile değerlendirilmiştir. İstatistiksel değerlendirmede SPSS paket programı (SPSS 21.0, Inc, Chicago, ABD) kullanılmış ve sonuçlarda $p$ değeri $0,05^{\prime}$ ten küçük olanlar anlamlı kabul edilmiştir.

\section{BULGULAR}

Ankete katılan bireylerin en fazla doğru yanıtladıkları diş 
hekimliği uzmanlık alanı Ağız, Diş ve Çene Radyolojisi, en fazla yanlış yanıtladıkları alan Periodontoloji olurken; "bilmiyorum" yanıtı en fazla Restoratif Diş Tedavisi için verilmiştir. ilk kez diş hekimine gelen bireylerde ise en fazla doğru bilinen uzmanlık alanı Ağız, Diş ve Çene Cerrahisi, en fazla yanlış cevabın verildiği bölümler Restoratif Diş Tedavisi ve Periodontoloji olmuştur. Hastaların cevaplarının uzmanlık alanlarına göre dağılımı Tablo 1'de verilmiştir.

Tablo 1. Hastaların verdikleri cevapların uzmanlık alanlarına göre dağılımı

\begin{tabular}{llll}
\hline Uzmanlık Alanı & $\begin{array}{l}\text { Doğru } \\
(\%)\end{array}$ & $\begin{array}{l}\text { Yanlış } \\
(\%)\end{array}$ & $\begin{array}{l}\text { Bilmiyorum } \\
(\%)\end{array}$ \\
\hline Ağız, Diş ve Çene Cerrahisi & 47,6 & 8,6 & 43,8 \\
Periodontoloji & 14,3 & 41 & 44,8 \\
Çocuk Diş Hekimliği & 60 & 11,4 & 28,6 \\
Endodonti & 27,6 & 25,7 & 46,7 \\
Ağız, Diş ve Çene Radyolojisi & 62,9 & 7,6 & 29,5 \\
Restoratif Diş Tedavisi & 17,1 & 33,3 & 49,5 \\
Ortodonti & 41,9 & 26,7 & 31,4 \\
Protetik Diş Tedavisi & 34,3 & 19 & 46,7
\end{tabular}

Diş hekimi olmayan 38 personelimiz; Ağız, Diş ve Çene Cerrahisi, Çocuk Diş Hekimliği, Ağız, Diş ve Çene Radyolojisi ve Ortodonti bölümlerini \%100 doğru yanıtlamıştır. En fazla yanlış yanıt verilen bölüm Restoratif Diş Tedavisi'dir. Personelin verdiği cevapların dağılımı Tablo 2'de gösterilmiştir.

Tablo 2. Personelin vermiş oldukları cevapların uzmanlık alanlarına göre dağılımı

\begin{tabular}{llll}
\hline Uzmanlık Alanı & $\begin{array}{l}\text { Doğru } \\
(\%)\end{array}$ & $\begin{array}{l}\text { Yanlıș } \\
(\%)\end{array}$ & $\begin{array}{l}\text { Bilmiyorum } \\
(\%)\end{array}$ \\
\hline Ağız, Diș ve Çene Cerrahisi & 100 & 0 & 0 \\
Periodontoloji & 97,4 & 2,6 & 0 \\
Çocuk Diș Hekimliği & 100 & 0 & 0 \\
Endodonti & 86,8 & 13,2 & 0 \\
Ağız, Diș ve Çene Radyolojisi & 100 & 0 & 0 \\
Restoratif Diș Tedavisi & 84,2 & 15,8 & 0 \\
Ortodonti & 100 & 0 & 0 \\
Protetik Diș Tedavisi & 94,7 & 5,3 & 0 \\
\hline
\end{tabular}

Anketimize katılan 1000 bireyin yarıya yakın kısmı $(\% 46,6)$ lisans mezunudur, eğitim durumlarına göre dağılım grafiği Resim 1'de, gelir dağılımları grafiği Resim 2'de verilmiştir. Katıımcıların \%34,3'ünün yakın çevresinde ya da ailesinde diş hekimi bulunmaktadır. Medeni durum dağılımlarında \%50'sinin evli, \%48'inin bekar \%2'lik kesimin boşanmış olduğu görülmüştür.

Bireylerin diş hekimi ziyaret sıklıkları Resim 3'te gösterilmektedir. Büyük çoğunluk $(\% 46,7)$ ağrım olduğunda diş hekimine gidiyorum seçeneğini işaretlemiştir, \%3, $8^{\prime}$ lik kitle ise ilk kez diş hekimine geldiğini belirtmiştir.

Katıımcıların yakın çevrelerinde ya da ailelerinde diş hekimi olması ile verdikleri cevaplar arasında anlamlı ilişki gözlenmemiştir ( $p>0,05)$. Medeni durum parametresi de anlamlı fark oluşturmamıştır $(p>0,05)$.

Kadın ve erkek cinsiyeti karşılaştırıldığında verilen cevaplarda Restoratif Diş Tedavisi erkekler tarafından daha fazla doğru yanıtlanırken $(p<0,05)$ Protetik Diş Tedavisi kadın- lar tarafından daha fazla doğru cevaplanmıştır $(p<0,05)$. Cinsiyet parametresi diğer uzmanlık alanlarında anlamlı fark oluşturmamıştır $(p>0,05)$.

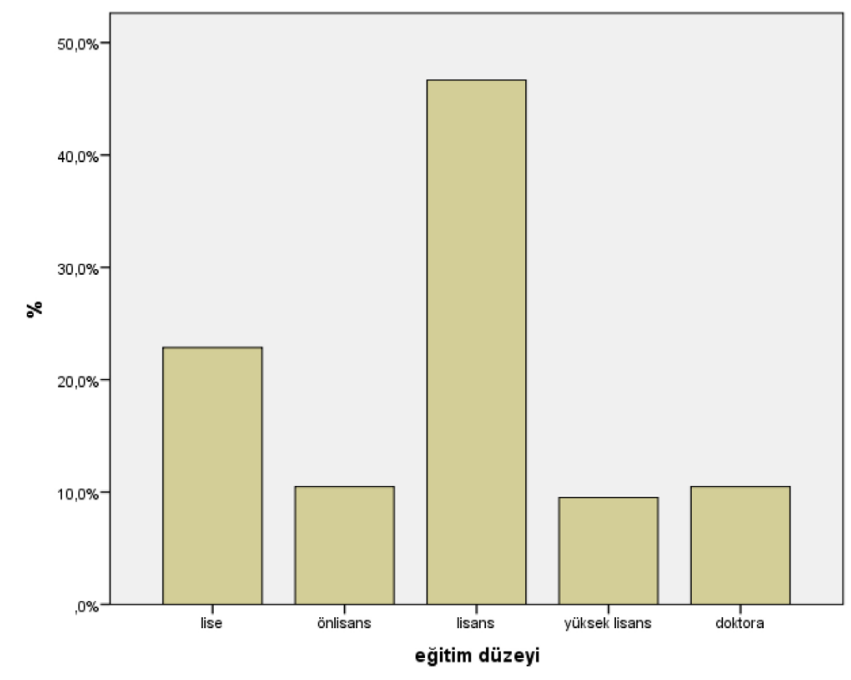

Resim 1. Bireylerin eğitim durumlarına göre dağılımı

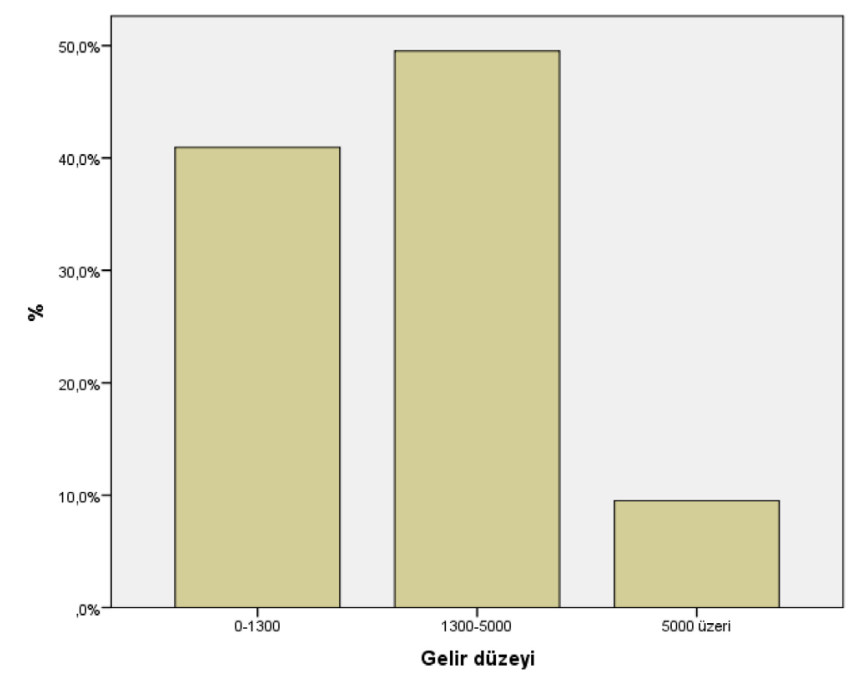

Resim 2. Bireylerin gelir düzeylerine göre dağılımı

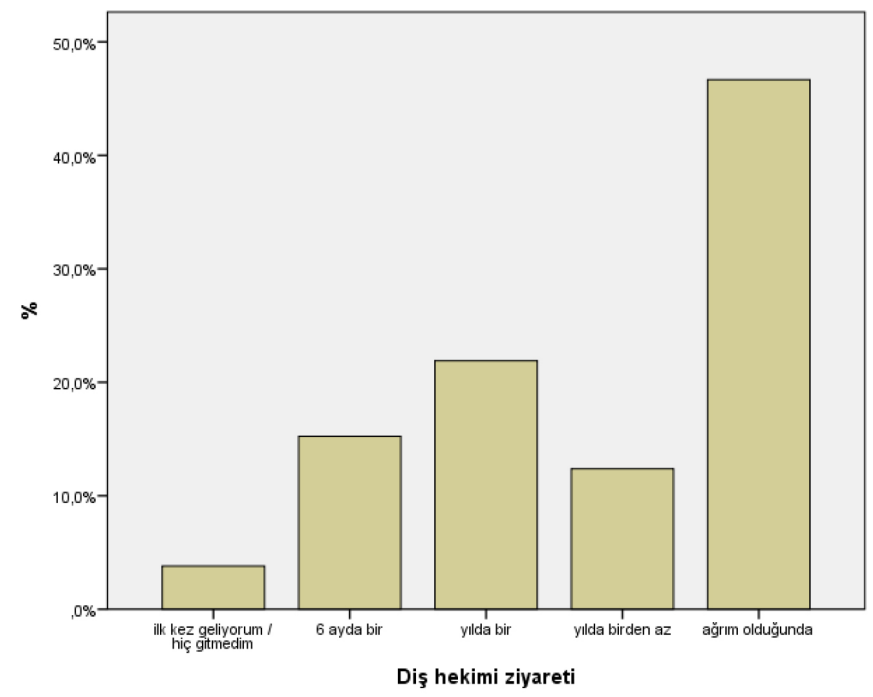

Resim 3. Bireylerin diş hekimi ziyaret sıklıkları

Eğitim durumlarına göre verilen cevaplar incelendiğinde yalnızca Periodontoloji için anlamlı fark saptanmıştır $(p<0,05)$. Lise ve önlisans seviyesindeki eğitim durumu- 
na sahip bireylerin doğru cevap verme oranlarının diğerlerinden daha düşük olduğu görülmüştür.

Gelir dağılımı parametresi Periodontoloji, Restoratif Diş Tedavisi ve Çocuk Diş Hekimliği bölümlerinde anlamlı fark oluşturmuştur $(p<0,05)$. Her üç uzmanlık alanının doğru bilinme oranı gelir seviyesi ile doğru orantılı bir artış göstermektedir.

Hastaların diş hekimi ziyaretlerinin sıklığı Periodontoloji ve Endodonti bölümleri için verilen cevaplarda anlamIı fark oluşturmuştur $(p<0,05)$. Yılda bir kez diş hekimini ziyaret edenlerin, ilk kez müracaat edenler ve ağrım olduğunda geliyorum seçeneğini işaretleyenlerden daha fazla doğru cevap verdiği görülmüștür.

\section{TARTIŞMA}

Literatürde bireylerin diş hekimliği alanında çeşitli konulardaki bilgi ve farkındalık düzeylerinin incelendiği çeşitli çalışmalar bulunmakla birlikte, toplumun diş hekimliği uzmanlık alanları konusundaki bilgi düzeyini değerlendiren bir çalışma bulunmamaktadır. Güngör ve Dikeç, ${ }^{8}$ Doğu Anadolu Bölgesi'nde 190 hastanın implant tedavisi hakkındaki bilgi düzeylerini değerlendirmiş, katılımcıların $\% 30,5^{\prime} \mathrm{i}$ hiçbir bilgiye sahip olmadığını söylemiştir, $\% 53,7$ 'si kısmen bilgiye sahip olduklarını söylemişlerdir ve geri kalan $\% 15,8^{\prime}$ lik oran ise yeterli bilgiye sahip olduklarını söylemişlerdir. Araştırmacılar Protetik Diş Tedavisi kliniğine başvuran hastalar üzerinde gerçekleştirilen çalışmanın sonuçlarının diğer toplumlardan göstermiş olduğu farklılığın sebebinin, farklı toplumlardaki sosyo-ekonomik ve kültürel farklardan kaynaklandığını belirtmişlerdir.

Barbosa ve ark. ${ }^{9}$ nın uyguladıkları anket sonuçlarına göre dişsiz hastaların dental hijyen ve protez bakımı konusundaki bilgileri yetersizdir. Protetik tedavi uygulaması hasta-hekim ilişkisinin ve oral hijyen sürdürülmesinin ilk aşamasını oluşturmakta ve bu çalışma hekimin tedavi esnasında hastasını oral hijyen ve bakım konusundaki motivasyonunun gerekliliğini ortaya koymaktadır.

Shetty ve ark. ${ }^{10^{\prime}}$ nın Hindistan'da 200 diş hekimi ile gerçekleştirdikleri ankette hekimlerin Konik Işınlı Bilgisayarlı tomografi konusundaki bilgi düzeyleri değerlendirilmiş ve Konik Işınlı Bilgisayarlı tomografi'nin öğretim hayatında daha fazla yer bulması gerektiği sonucuna ulaşıımıştır. Booshehri ve ark. ${ }^{11}$ tarafından İran'da 102 diş hekimi ile radyasyondan korunma konusundaki bilgi düzeyi değerlendirilmiş ve bu konudaki bilgi seviyesinin düşük olduğu gözlenmiştir.

Ersin ve ark. ${ }^{12}$ İzmir'de 4 farklı ilköğretim okulunda 100 öğretmene dental travma ile ilgili bilgi düzeylerinin değerlendirildiği bir anket uygulamışlar ve sonuçta öğretmenlerin dental travmalarla ilgili yeterli bilgiye sahip olmadıkları sonucuna ulaşmışlardır. Çalışmada öğretmenlerin hizmet süreleri ile dental travma ilkyardımı bilgisi arasında doğru orantı olduğu görülmüş ve dental travmalara okullarda çok sık rastlanması sebebiyle öğretmenlerin konu ile ilgili bilgi düzeylerinin arttırımasının gerekliliği sonucuna varılmıştır.

Al-Shammari ve ark. ${ }^{13}$ sigara içen ve içmeyen 1012 bireyde sigaranın ağız sağlığına etkisi konusundaki farkındalıkları karşılaştırmışlar ve sigara içen bireylerde farkındalık düzeyinin içmeyenlere göre anlamlı şekilde düşük olduğunu gözlemlemişlerdir. Sigara içme alışkanlığı ile eğitim düzeyi de ilişkili bulunduğundan toplumda konu ile ilgili yapılacak bilgilendirmelere gereksinim duyulmaktadır. Bizim elde ettiğimiz sonuçlarda da lise ve önlisans eğitim düzeyindeki bireyler, yüksek lisans ve doktora seviyesinde eğitimli bireylerden daha fazla yanlış cevap verme eğilimindeydi. Bu sonuç eğitimin halk sağlığı üzerindeki etkisini yansıtmaktadır.

Tosun ve ark. ${ }^{1{ }^{\prime}} \mathrm{n} ı n$ Ağız, Diş ve Çene Cerrahisi kliniğine başvuran 300 gönüllü ile diş hekimliğinde lazer farkındalığı üzerine yaptıkları çalışmada eğitim düzeyi ve diş hekimi ziyaret sıklığı arttıkça farkındalık düzeyinin artış gösterdiğini saptamışlardır. Benzer şekilde Yucel ve ark. ${ }^{15}$ 224 tıp fakültesi hastasında uygulanan iyonize radyasyon konusundaki bilgi düzeyi anket sonuçlarında eğitim düzeyleri yüksek olanlarda ve daha önceden radyolojik tetkik yaptıranlarda anlamlı derecede yüksek skorlar elde etmişlerdir.

Canger ve ark. ${ }^{16}$ Kayseri ve çevresinde yaşayan, diş hekimliği fakültesine başvuran 1206 bireye diş hekimliği radyolojisi farkındalığını ölçmek için uyguladıkları ankette, katıımcıların radyasyonun zararları gibi bazı konularda yeterli bilgi sahibi olmalarıyla birlikte, diğer konularda yetersiz bilgiye sahip oldukları ve bilgi düzeylerinin arttırılması gerektiği sonucuna ulaşmışlardır. Katılımcıların büyük çoğunluğunun düzenli diş hekimine gitmeyen bireyler olması nedeniyle de bilgi düzeyinin artırılmasında diş hekimi ziyaretlerinin önemi ortaya çıkmaktadır. Konu ile ilgili olarak hastaların tedavi merkezlerinde broşürler sunularak ya da basın-yayın organları vasıtası ile bilgilendirilmelerinin gerekliliği ortaya konmuştur. Bizim çalışmamızın bulguları incelendiğinde de katılımcıların büyük çoğunluğunun düzenli olarak diş hekimine gitmediği anlaşılmıştır. Yarıya yakın katıımcı 'ağrım olduğunda diş hekimine gidiyorum' seçeneğini işaretlemiştir. Tamamı lise ve üzeri eğitim düzeyine sahip katıımcılarımızın düzenli diş hekimi ziyaretlerinin olmayışı toplumun genelindeki zayıf ağız-diş sağlığının açıklayıcısı olarak görülmekle birlikte diş hekimliği uzmanlık alanları konusundaki bilgi düzeylerinin düşük seviyede kalması bu durumla ilişkilendirilebilir.

Illk kez diş hekimine gelen bireyler çalışma grubumuzun $\% 3,8$ 'ini oluşturmaktadır. Illk kez gelen bireylerin en fazla doğru yanıtladığı bölüm Ağız, Diş ve Çene Cerrahisi olmuştur. Tüm bireyler değerlendirildiğinde ise bu 
cevabın yerini Ağız, Diş ve Çene Radyolojisi almıştır. Bu sonuç diş hekimliği fakültelerinde tüm hastaların ziyaret ettiği bölümün Ağız, Diş ve Çene Radyolojisi olmasından kaynaklanabilir. Buna bağlı olarak toplumda diş hekimliğinde uzmanlık farkındalığının artırılmasında en önemli rol Ağız, Diş ve Çene Radyolojisi kliniklerine düşmekte ve burada yapılacak bilgilendirmeler önem kazanmaktadır. Cabbar ve ark. ${ }^{17} 301$ diş hekimliği hastasında AIDS bulaş yolları konusundaki bilgi düzeylerini ölçmek için uyguladıkları ankette, hastaların kabul edilebilir seviyede bilgiye sahip oldukları sonucunu elde etmişlerdir. Basın-yayın organlarının konu ile ilgili bilgilendirmeleri ve hastaların HIV ile enfekte olma korkusu bilginin kaynağı olarak düşünülebilir. Kamu sağlığı bilinci üzerindeki etkisi göz önüne alındığında, diş hekimliğinde uzmanlık konusunun medyada daha fazla yer bulması ile bilgi düzeyi arttırılabilecektir.

Peker ve ark. ${ }^{18} 1022$ katılımcı üzerinde oral kanserler konusunda toplumun bilgi düzeyini değerlendirmişler ve toplumun düşük seviyedeki bilgi düzeyinin medya organları aracılığı ile arttırılabileceği sonucuna varmışlardır. Dental fobi nedeni ile bazı hastalar orofasiyal bölge şikayetleri için diş hekimleri yerine tıp hekimlerine gitmektedirler, bununla ilişkili olarak Azodo ve ark. ${ }^{1} 142$ tıp doktoru ile yaptıkları anket çalışmasında hekimlerin diş hekimliği uzmanlığı gerektiren uygulamalarla ilgili bilgi düzeylerini değerlendirmişler ve yalnızca \%5,6'lık kesimin iyi düzeyde bilgiye sahip olduğunu tespit etmişlerdir. Daha önce dental tedavi geçmişi olan tıp hekimlerinin konu ile ilgili bilgi düzeylerinin daha yüksek olduğu görülmüştür. Çalışmamızın sonuçlarına göre düzenli diş hekimi ziyareti olan bireylerin daha fazla doğru cevap verme eğiliminde olduğu saptanmıștır. Toplumun diș hekimliğinde uzmanlık konusundaki bilgi düzeyinin düzenli diş hekimi ziyaretleri ile artırılması olası görünmektedir.

Nijerya'da tıp fakültesi öğrencileri ile yapılan bir çalışma, öğrencilerin bir diş hekimliği uzmanlık alanı olan Ortodonti ve maloklüzyanlarla ilgili yeterli bilgiye sahip olmadıklarını ortaya koymuştur. ${ }^{19}$ Bu sonucu katıımcıların diş hekimi ziyaret sıklığının düşük seviyede olmasına bağlı olarak diş hekimliği alt dallarının varlığından habersiz olmaları ile ilişkilendirmişlerdir.

Adeghe ve ark. ${ }^{20}$ 4, 5, ve 6. sınıflardaki 279 tıp fakültesi öğrencisinde diş hekimliği uzmanlık alanları konusundaki bilgi düzeyini ölçmüş, daha üst sınıf öğrencilerde, kadın cinsiyette ve daha önceden diş hekimi tedavisi geçirenlerde bilgi düzeyinin yüksek olduğu sonucunu elde etmişlerdir. Cinsiyet farkını da kadınların daha sıklıkla diş hekimi ziyareti yapmaları ile ilişkilendirmişlerdir.

Çalışmamı diş hekimliği fakültesi hastaları ile gerçekleştirilmiş olup, tamamı internet kullanan, lise ve üzeri eğitime sahip bireylerdir. Çalışma grubumuzun yarıya yakın kısmı lisans mezunudur (\%46,7), TUIK 2014 verilerine göre ise
Türkiye'de önlisans ve lisans mezunu oranı \%12,93 olarak açıklanmıştır. Bu nedenle toplumun genelinde bu konudaki bilgi seviyesinin daha düşük olması beklenebilir.

Periodontoloji ve Restoratif Diş Tedavisi uzmanlık alanları anket uyguladığımız personel ve hastalar içinde en az bilgi sahibi olunan ya da yanlış cevap verilen bölümlerdir. Çalışma grubumuz ağırlıklı olarak 1300-5000TL geliri olan bireylerden oluşmaktadır. Gelir düzeyindeki artışla beraber bilgi düzeyi her iki bölüm için de artış göstermiştir. Bunun yanı sıra Periodontoloji uzmanlık alanı için doğru cevap verme oranı eğitim durumu ile ilişkilidir, lisans ve lisansüstü bireyler tarafından anlamlı ölçüde daha fazla bilinme oranına sahiptir. Diş hekimi ziyaret sıklığı da bilgi düzeyini anlamlı şekilde artırmıştır. Bu sonuçlar sosyo-ekonomik düzey ve eğitim seviyesinin, bireylerin ağız-diş sağlığı konusuna verdikleri önemi artırdığını ortaya koymaktadır.

Daha önce toplumun ya da diş hekimine müracaat eden hasta populasyonunun diş hekimliği uzmanlıkları konusu üzerine bilgimiz dahilinde literatürde benzer bir çalışma yapılmadığı için sonuçlarımızı karşılaştırarak tartışma olanağı bulunamamıştır.

\section{SONUÇ}

Diş hekimliğinde uzmanlık, 2011 yılı itibarıyla resmiyet kazanmış bir uygulama olup bireylerin bu konudaki bilgi düzeyi halen yeterli seviyede değildir. Bu konuda hastaların ilk muayenelerinin yapıldığı Ağız, Diş ve Çene Radyolojisi bölümünde yapılacak bilgilendirmeler yararlı olabilir. Medya organlarının desteği ile toplumun düzenli diş hekimi ziyaretlerinin sağlanması da faydalı olacaktır. Gelecek çalışmalarda toplumun bilgi düzeyini ölçmeye yönelik, daha geniş homojen kitlelerde değerlendirme yapılmasının faydalı olacağı düşüncesindeyiz.

\section{KAYNAKLAR}

1.Azodo CC, Ehigiator O, Ehizele AO. Medical doctors' knowledge of dental specialty: Implication for referral. Saratov J Med Sci Res 2010; 6: 140-143.

2.Efeoğlu A, Erdemir AD, Öncel Ö. Başlangıçtan Günümüze Diş Hekimliği. İstanbul; Nobel Tıp Kitabevleri: 2000. s.1.

3.Noras Y. Diş Hekimliği Tarihi. Ankara; Hacettepe Üniversitesi Yayınları: 1973. s.4-11.

4.Aydıntuğ SY. 20. Yüzyılda Türk Askeri Diş Hekimliği Tarihi. Tıp Tarihi ve Etik Anabilim Dalı Doktora Tezi, Ankara Üniversitesi Sağlık Bilimleri Enstitüsü: 2011.

5.Peck S. The students of Edward Hartley Angle, the first specialist in orthodontics: a definitive compilation. J Hist Dent 2006; 54: 70-76.

6.Peck S. The contributions of Edward $\mathrm{H}$. Angle to dental public health. Community Dent Health 2009; 26: 130131. 
7.26 Nisan 2011 tarihli ve 27916 sayılı Resmi Gazete.

8.Güngör H, Dikeç EV. Doğu Anadolu Bölgesi'nde implant tedavisi hakkında hastaların bilgi düzeyinin araştırılması. J Dent Fac Atatürk Uni 2015; 2: 205-212.

9.Barbosa LC, Ferreira MRM, Calabrich CFC, Viana AC, Lemos MCL, Lauria RA. Edentulous patients' knowledge of dental hygiene and care of prostheses. Gerodontology 2008; 25: 99-106.

10.Shetty SR, Castelino RL, Babu SG, Laxmana AR, Roopashri K. Knowledge and Attitude of Dentists towards Cone Beam Computed Tomography in Mangalore-A Questionnaire Survey. Austin J Radiol 2015; 2:1016-1021. 11.Booshehri MZ, Ardakani FE, Nozari H. Evaluation of dentists' awareness about personnel and patients national protection in Yazd dental office. Sci Res 2012; 4: 490-492.

12. Ersin N, Önçağ Ö, Ertuğrul F, Coşkun E, Kantar E, Kara $\mathrm{N}$, Akdemir Y. Illkokul öğretmenlerinin dental travmalarla ilgili bilgi düzeylerinin değerlendirilmesi. Ondokuz Mayıs Univ Dis Hekim Fak Derg 2011; 12: 63-68.

13.Al-Shammari KF, Moussa MA, Al-Ansari JM, Al-Duwairy YS, Honkala EJ. Dental patient awareness of smoking effects on oral health: Comparison of smokers and non-smokers. J Dent 2006; 34: 173-178.

14.Tosun $E$, Aktaş $A$, Bayram $H$, Yeniay Ö, Taşar F, Altay MA. Awareness and acceptance of lasers in dentistry in Turkish population. Clin Dent Res 2013; 37: 30-34.

15.Yucel A, Karakas E, Bulbul E, Kocar I, Duman B, Onur A. Knowledge about ionizing radiation and radiation protection among patients awaiting radiological examinations: A cross-sectional survey. Med J Kocatepe 2009; 10: 25-31.

16.Canger EM, Köse E, Ekinci B. Kayseri ve çevresindeki bir grup bireyin diş hekimliği radyolojisi farkındalığı. ADO J Clin Sci 2013; 7: 1381-1390.

17.Cabbar F, Süer BT, Çapar GD, Yıldız H, Tomruk CÖ. Dental patients' knowledge and awareness about transmission ways of acquired immune deficiency syndrome (AIDS). J Istanbul Unıv Fac Dent 2016; 50: 19-26.

18.Peker I, Alkurt MT. Public awareness level of oral cancer in a group of dental patients. J Contemp Dent Pract 2010; 11: 1-9.

19.Adegbite KO, Ogunbanjo BO, Ajisafe OA, Adeniyi AA. Knowledge of Orthodontics as a Dental Specialty: A Preliminary Survey among LASUCOM Students. Ann Med Health Sci Res 2012; 2: 14-18.

20.Adeghe HA, Ehigiator O, Azodo CC, Ehizele AO. Nigerian clinical level medical students' knowledge of dental specialty. Ann Med Heath Sci Res 2012; 2: 157-160. 